\title{
Abnormalities of thymic stroma may contribute to immune dysregulation in murine models of leaky severe combined immunodeficiency
}

\section{Francesca Rucci ${ }^{1}$, Pietro Luigi Poliani ${ }^{2}$, Stefano Caraffi ${ }^{1}$, Tiziana Paganini ${ }^{3}$, Elena Fontana ${ }^{2}$, Silvia Giliani ${ }^{3}$, Frederick W. Alt ${ }^{4}$ and Luigi Daniele Notarangelo ${ }^{1}{ }^{*}$}

1 Division of Immunology and The Manton Center for Orphan Disease Research, Children's Hospital Boston, Boston, MA, USA

${ }^{2}$ Department of Pathology, University of Brescia, Brescia, Italy

3 "Angelo Nocivelli" Institute for Molecular Medicine and Department of Pediatrics, University of Brescia, Brescia, Italy

${ }^{4}$ Howard Hughes Medical Institute, Children's Hospital, Immune Disease Institute and Harvard Medical School, Boston, MA, USA

\section{Edited by:}

Menno C. Van Zelm, Erasmus MC, University Medical Center,

Netherlands

\section{Reviewed by:}

Mirjam Van der Burg, Erasmus MC, Netherlands

Pärt Peterson, University of Tartu, Estonia

\section{*Correspondence.}

Luigi Daniele Notarangelo, Division of Immunology and The Manton Center for Orphan Disease Research, Karp

Research Building, Room 9210, 1

Blackfan Circle, Boston, MA 02115,

USA

e-mail: luigi.notarangelo@

childrens.harvard.edu
Lymphostromal cross-talk in the thymus is essential to allow generation of a diversified repertoire of $T$ lymphocytes and to prevent autoimmunity by self-reactive $T$ cells. Hypomorphic mutations in genes that control $\mathrm{T}$ cell development have been associated with immunodeficiency and immune dysregulation both in humans and in mice. We have studiedT cell development and thymic stroma architecture and maturation in two mouse models of leaky severe combined immune deficiency, carrying hypomorphic mutations in rag 1 and lig4 genes. Defective T cell development was associated with abnormalities of thymic architecture that predominantly affect the thymic medulla, with reduction of the pool of mature medullary thymic epithelial cells (mTECs). While the ability of mTECs to express autoimmune regulator (Aire) is preserved in mutant mice, the frequency of mature mTECs expressing Aire and tissue-specific antigens is severely reduced. Similarly, the ability of $\mathrm{CD} 4^{+} \mathrm{T}$ cells to differentiate into Foxp3 ${ }^{+}$natural regulatory $\mathrm{T}$ cells is preserved in rag 1 and lig4 mutant mice, but their number is greatly reduced. These data indicate that hypomorphic defects in T cell development may cause defective lymphostromal cross-talk and impinge on thymic stromal cells maturation, and thus favor immune dysregulation.

Keywords: severe combined immunodeficiency, recombination-activating gene 1, DNA ligase 4, thymic epithelial cells, thymus, dendritic cells, Aire, regulatory $\mathrm{T}$ cells

\section{INTRODUCTION}

The thymus is a highly specialized lymphoid organ whose peculiar microenvironment supports homing, proliferation, survival, maturation, and migration of immature thymocytes (Takahama, 2006).

Upon entrance in the thymus, bone marrow-derived committed lymphoid progenitors undergo multiple rounds of proliferation and a distinct process of cell differentiation that culminates with the emergence of a diversified pool of mature $\mathrm{T}$ cells whose randomly generated $\mathrm{T}$ cell-receptor (TCR) repertoire has been selected for self-major-histocompatibility-complex (MHC) restriction and purged of self-reactive specificities.

Thymocyte development and selection are supported by the thymic stroma, that includes a highly organized network of specialized thymic epithelial cells (TECs) and distinct populations of thymic dendritic cells (DCs). The mature thymus is organized in two major compartments, the cortex and the medulla, that contain distinct populations of TECs that exert different functions. In particular, cortical TECs (cTECs) sustain the positive selection of $\mathrm{CD}^{+}{ }^{\mathrm{CD}} 8^{+}$double positive (DP) thymocytes that have successfully rearranged their TCR; in contrast, medullary TECs (mTECs) support selection, maturation, and export of single positive (SP) thymocytes (Anderson and Jenkinson, 2001; Hogquist et al., 2005; Irla et al., 2010; Takahama et al., 2010).

Moreover, mTECs display the unique ability of expressing the transcription factor autoimmune regulator (Aire), that allows mTECs to express a large number of genes that encode for peripheral tissue-specific antigens (TSAs). These self TSAs are presented to developing SP T cells either directly by mTECs or indirectly by DCs upon uptake from mTECs (Derbinski et al., 2005; Kyewski and Klein, 2006). Interaction between self-antigen-loaded thymic stromal cells and newly generated $\mathrm{T}$ cells expressing self-reactive TCR specificities leads to the induction of central $\mathrm{T}$ cell tolerance via clonal deletion of self-reactive $\mathrm{T}$ cells. Alternatively, it has been proposed that mTECs and medullary thymic DCs may contribute to the establishment of tolerance by facilitating diversion of self-reactive thymocytes into natural regulatory $\mathrm{T}$ (nTreg) cells, that exhibit suppressive properties when exposed to selfantigens in the periphery (Watanabe et al., 2005; Miyara and Sakaguchi, 2007). These observations indicate that the thymus plays a critical role not only in the generation of a functional and diversified repertoire of mature $T$ cells that are capable of recognizing non-self-antigens, but also in preventing the development of autoimmunity. 
Primary immunodeficiencies (PIDs) comprise a heterogeneous group of genetic disorders characterized by impaired development and/or function of the immune system (Fischer, 2007; Notarangelo, 2010). In humans, several genetic defects have been identified that result in block at early stages of $\mathrm{T}$ cell development: in some of these forms, B and/or NK cell development is also impaired. These disorders are collectively known as severe combined immune deficiency (SCID), whose clinical phenotype is characterized by early onset susceptibility to infections and failure to thrive. SCID is inevitably fatal unless immune reconstitution is achieved by hematopoietic cell transplantation or, in selected cases, by enzyme replacement therapy or gene therapy (Buckley, 2000; Fischer, 2000).

In humans, up to $20-30 \%$ of all cases of SCID are caused by defects of $\mathrm{V}(\mathrm{D}) \mathrm{J}$ recombination, a lymphoid-restricted process that allows DNA rearrangements at the immunoglobulin and TCR loci, enabling expression of immunoglobulin and TCR proteins and development of a diversified repertoire of $\mathrm{T}$ and $\mathrm{B}$ lymphocytes.

Mutations of the recombination-activating gene (RAG) 1 and RAG2 cause SCID by interfering with the initial step of $V(D) J$ recombination, i.e., recognition of recombination signal sequences that flank the Variable (V), Diversity (D), and Joining (J) coding elements and introduction of DNA double strand breaks (DSBs; Schwarz et al., 1996). In contrast, mutations of Artemis, DNA protein kinase catalytic subunit (DNA-PKcs), DNA ligase 4 (LIG4), and Cernunnos/XLF affect the non-homologous end joining (NHEJ) pathway of DNA repair, that is involved at later stages in V(D)J recombination (Riballo et al., 1999; Moshous et al., 2001; Buck et al., 2006a; van der Burg et al., 2009).

While null mutations in genes involved in $\mathrm{V}(\mathrm{D}) \mathrm{J}$ recombination typically cause SCID with virtual absence of T and B lymphocytes ( $\left.\mathrm{T}^{-} \mathrm{B}^{-} \mathrm{SCID}\right)$, hypomorphic mutations in the same genes in humans have been associated with variable degrees of impairment of $\mathrm{T}$ and $\mathrm{B}$ cell development and frequent occurrence of manifestations of immune dysregulation. In particular, Omenn syndrome (OS) is characterized by oligoclonal expansion of few T cell clonotypes that infiltrate peripheral organs and cause extensive tissue damage (erythroderma, gut villous atrophy, hepatosplenomegaly; Villa et al., 2001). Less severe defects in V(D)J recombination may cause more subtle phenotypes, ranging from leaky SCID (in which residual development of $\mathrm{T}$ cells is not associated with generalized skin rash) to delayed-onset combined immunodeficiency with granulomatous manifestations (Schuetz et al., 2008; De Ravin et al., 2010). Furthermore, hypomorphic mutations in genes involved in NHEJ are associated also with extra immune clinical features (microcephaly, short stature, increased occurrence of malignancies), reflecting impairment of DNA repair mechanisms (O'Driscoll et al., 2004; Gennery, 2006; Sobacchi et al., 2006).

We have previously reported severe abnormalities of thymic architecture and impaired expression of Aire and of TSAs in the thymus of patients with OS (Cavadini et al., 2005; Poliani et al., 2009). These observations imply that genetic defects that affect $T$ cell development and prevent generation of a robust and diversified $\mathrm{T}$ cell repertoire may also impinge on the differentiation and/or homeostasis of thymic stromal cells, and hence impair deletional and non-deletional mechanisms of central tolerance.
In order to address this hypothesis, we have taken advantage of two recently described murine models of leaky SCID: the lig $4^{R / R}$ mouse, homozygous for the hypomorphic R278H mutation in the lig4 gene (Rucci et al., 2010) and the $\mathrm{rag}^{\mathrm{S} / \mathrm{S}}$ mouse, carrying the homozygous hypomorphic S723C substitution in the rag1 gene (Giblin et al., 2009; Walter et al., 2010).In agreement with the human phenotype, both mutant mice are characterized by severe immunodeficiency with residual development of oligoclonal and functionally impaired T cells. In addition, a minority of $\mathrm{rag} 1^{S / S}$ mice (but not lig $4^{R / R}$ mice) develop features consistent with OS (Giblin et al., 2009; Walter et al., 2010). Here we show that hypomorphic mutations that affect $\mathrm{V}(\mathrm{D}) \mathrm{J}$ recombination also compromise architecture and homeostasis of thymic stroma, and that the severity of thymic abnormalities correlates with the degree of immune dysregulation that may be observed in these conditions.

\section{MATERIALS AND METHODS MICE}

Mice harboring the rag1 S723C mutation ( $r a g 1^{\mathrm{S} / \mathrm{S}}$; Giblin et al., 2009) and the lig4 R278H mutation (lig $4^{R / R}$; Rucci et al., 2010) were housed at the Karp Family Research Building under specific pathogen-free conditions. Animal experiments were carried out after approval and in accordance with guidelines from the Subcommittee on Research Animal Care of Children's Hospital Boston, Harvard Medical School.

\section{SINGLE CELL SUSPENSIONS PREPARATION}

Single cell suspensions were prepared from thymuses of $l i g 4^{R / R}$, $\operatorname{rag} 1^{S / S}$, and wild-type (WT) mice. Tissues were homogenized on $70 \mu \mathrm{m}$ cell strainers (BD Falcon, Bedford, MA, USA) using FACS buffer: Dulbecco's Phosphate-Buffered Saline (D-PBS, GIBCO from Invitrogen, Grand Island, NY, USA) containing $2 \%$ of heat inactivated and filtered fetal calf serum (FCS, from Gemini BioProducts, West Sacramento, CA, USA). Red blood cell lysis was performed at room temperature by adding $2 \mathrm{ml}$ of Red Blood Cell Lysing Buffer (Sigma Aldrich Inc., St Louis, MO, USA) for $10 \mathrm{~min}$ before proceeding with the specific stainings.

Thymic stromal cells were isolated as previously published (Gray et al., 2002) by digesting thymuses from $\operatorname{lig} 4^{R / R}, \mathrm{rag}^{\mathrm{S} / \mathrm{S}}$, and WT mice with $0.125 \%(\mathrm{w} / \mathrm{v})$ collagenase D with $0.1 \%(\mathrm{w} / \mathrm{v})$ DNAse I (both from Roche, Indianapolis, IN, USA) in RPMI 1640 (GIBCO from Invitrogen, Grand Island, NY, USA).

\section{IMMUNOPHENOTYPIC ANALYSIS}

Thymocytes were incubated with the following antibodies: antigen-presenting cells (APC)-conjugated anti-CD4, biotinconjugated or PE-conjugated anti-CD8, biotin-conjugated antiCD4, biotin-conjugated anti-B220, biotin-conjugated antiCD11b, biotin-conjugated anti-Gr1, FITC-conjugated anti-CD44, PE-conjugated anti-CD25, FITC-conjugated anti-CD69, biotinconjugated anti-Qa2 (all from BD Biosciences, San Jose, CA, USA). Samples stained with biotin-conjugated antibodies underwent additional incubation with PerCp-conjugated streptavidin. Intranuclear staining for Foxp3 was performed using APCconjugated anti-mouse/rat Foxp3 staining set (eBioscience, San Diego, CA, USA) following manufacturer's instructions. At least 
20,000 alive cells (defined by physical parameters) were acquired on a FACSCalibur system or FACS Canto (BD Biosciences, San Jose, CA, USA) and analyzed with FLOW-JO software (version 8.3; Treestar Inc.).

Analysis of TECs was performed staining single cell suspensions of stromal cells with PerCp-conjugated anti-CD45, PE-conjugated anti-Ly51, FITC-conjugated anti-MHC-II (BD Biosciences, San Jose, CA, USA). Intranuclear staining for Aire was performed after fixing stromal cells labeled with surface markers, by permeabilization with the BD CytoFix/CytoPerm Fixation/Permeabilization kit (BD Biosciences, San Jose, CA, USA). Anti-Aire antibody (5H12) was a kind gift from Dr. H. Scott (Hubert et al., 2008).

Analysis of thymic DCs was performed staining single cell suspensions of stromal cells with the following antibodies: APCconjugated anti-CD11c, PE-conjugated anti-CD45RA, biotinconjugated anti-CD3, anti-Ter119, anti-Gr1, anti-F4/80, antiCD19, anti-CD11b, anti-CD90 (BD Biosciences, San Jose, CA, USA). Analysis was performed after gating out the biotinylated positive population. At least 100,000 alive cells (defined by physical parameters) were acquired on a FACS Canto (BD Biosciences, San Jose, CA, USA) and analyzed with FLOW-JO software (version 8.3; Treestar Inc.).

\section{IMMUNOHISTOCHEMISTRY AND IMMUNOFLUORESCENCE}

Formalin-fixed paraffin embedded tissue sections were stained with hematoxylin and eosin (H\&E) and subjected in parallel to immunohistochemistry. Briefly, sections were deparaffinized, rehydrated, and endogenous peroxidase activity was blocked in $0.3 \% \mathrm{H}_{2} \mathrm{O}_{2} /$ methanol solution for $20 \mathrm{~min}$ prior to heat induced antigen retrieval (when necessary) using a thermostatic bath or a microwave-oven in $1.0 \mathrm{mM}$ EDTA ( $\mathrm{pH} 8.00$ ) or $1.0 \mathrm{mM}$ citrate buffer ( $\mathrm{pH}$ 6.00) respectively. Sections were then washed in TRIS-base buffer at $\mathrm{pH} 7.4$ and incubated for $1 \mathrm{~h}$ with the following reagents diluted in TRIS/1\% bovine serum albumin (BSA): rabbit anti-CK5 (1:50; Covance, Berkeley, CA, USA), rat antiCK8 (1:200; clone TROMA-1; kindly provided by Dr. U.H. von Andrian, Harvard Medical School), rabbit anti-claudin 4 (1:100; Zymed Laboratories, San Francisco, CA, USA), rabbit anti-murine Aire (1:3000; kindly provided by Dr. P. Peterson, University of Tartu, Estonia), and biotin-conjugated Ulex europaeus agglutinin1 (UEA-1; 1:600; Vector Laboratories, Burlingame, CA, USA). After washes, single immunostains were revealed using the ChemMATE Envision Rabbit/Mouse (DAKO Cytomation, Glostrup, Denmark) or NovoLinkTM Polymer Detection System (NovocastraTM Laboratories Ltd, Newcastle Upon Tyne, United Kingdom) followed by diaminobenzidine (DAB) as chromogen and Hematoxylin as counterstain.

The same procedure was applied to double immunofluorescence stainings prior to the incubation with a secondary swine anti-rabbit FITC-conjugated antibody (1:30; DAKO Cytomation, Glostrup, Denmark) for CK5 and a rabbit anti-rat biotinylated antibody (1:200; Vector Laboratories, Burlingame, CA, USA) followed by Streptavidin-Texas Red (1:100; Southern Biotechnology Associates, Birmingham, AL, USA) for CK8. Sections were then counterstained with DAPI.

Images were acquired with an Olympus DP70 digital camera mounted on an Olympus BX60 microscope using Cell $^{\mathrm{F}}$ imaging software (Soft Imaging System $\mathrm{GmbH}$ ) and Adobe Photoshop Version 7.0 for the artwork.

RNA ISOLATION, cDNA PREPARATION, AND REAL-TIME PCR ANALYSIS RNA isolation was isolated from thymus single cell suspensions using the mirVana miRNA isolation kit, according to the manufacturer's protocol (Ambion from Applied Biosystems Inc., Foster City, CA, USA). Reverse transcription was then performed with qScript cDNA SuperMix (Quanta BioSciences, Inc., Gaithersburg, MD, USA) following manufacturer's instructions.

Real-Time PCR for quantitative expression of Aire and TSAs was performed using TaqMan Gene expression assay with the following assays on demand (all by Applied Biosystems Inc., Foster City, CA, USA): Mm00477461_m1 (Aire); Mm00487224_m1 (Cybp1a2); Mm00433188_m1 (Fabp2); Mm00731595_gH (Ins2); Mm00493214_m1 (EpCAM, used as internal control). Reactions were performed using $2 \mu \mathrm{l}$ of cDNA obtained from $1 \mu \mathrm{g}$ of thymic RNA in a final volume of $20 \mu \mathrm{l}$ using TaqMan PCR Master Mix 2x (Applied Biosystems Inc., Foster City, CA, USA) and specific Gene Expression Assay 20x. Amplification was performed in duplicates in the 7500 Real-Time PCR System (Applied Biosystems Inc., Foster City, CA, USA) and results were analyzed with the 7500 Real-Time PCR Software.

\section{ANALYSIS OF T CELL REPERTOIRE}

Analysis of $\mathrm{T}$ cell repertoire in the thymus of $\mathrm{WT}, \operatorname{ragl}^{\mathrm{S} / S}$ and lig $4^{R / R}$ mice was performed as previously described (Rucci et al., 2010).

\section{STATISTICS}

At least five to six mice per group were analyzed. Results are indicated as mean $\pm \mathrm{SE}$ or SD. $p$ values were determined by unpaired Student's $t$-test $(p<0.05=* ; p<0.01=* * ; p<0.005=* * *$; $p<0.001=* * * *)$.

\section{RESULTS Lig4 $^{\mathrm{R} / \mathrm{R}}$ AND rag1 ${ }^{\mathrm{S} / \mathrm{s}}$ MICE EXHIBIT AN INCOMPLETE BLOCK IN T CELL DEVELOPMENT}

The $\operatorname{lig} 4^{R / R}$ and $r a g 1^{S / S}$ mice carry mutations that impair different steps in the $\mathrm{V}(\mathrm{D}) \mathrm{J}$ recombination process. In particular, rag1 mutations interfere with the first step of the process, when DSBs are introduced in the DNA (Fugmann et al., 2000. In contrast, lig4 mutations impair the repair of these breaks (Rooney et al., 2004). Despite these differences, both mutations affect V(D)J recombination and cause an early but incomplete block in $\mathrm{T}$ cell development.

Both $\operatorname{lig} 4^{R / R}$ and $\mathrm{rag} 1^{S / S}$ mice showed a significant reduction in thymus size and cellularity (Figure 1A), with a significant decrease in the absolute numbers of thymic $\mathrm{CD} 4^{+} \mathrm{CD} 8^{+} \mathrm{DP}$ cells as well as of $\mathrm{CD}^{+}{ }^{+} \mathrm{CD} 8^{-}$and $\mathrm{CD} 4^{-} \mathrm{CD} 8^{+}$SP thymocytes as compared to what observed in WT mice (Figure 1B).

In both mutant models, this block in $\mathrm{T}$ cell development was associated with a relative enrichment in the proportion of $\mathrm{CD} 4^{-}$ $\mathrm{CD}^{-}$double negative (DN)cells, that was particularly prominent in $\mathrm{rag}^{\mathrm{S} / \mathrm{S}}$ mice (\% DN cells $\pm \mathrm{SE}$ : WT $1.78 \pm 0.13 ; \operatorname{lig} 4^{R / R}$ $25.48 \pm 3.5 ; \operatorname{rag}^{S / S} 90.59 \pm 3.27$; WT vs. $\operatorname{lig} 4^{R / R}, p<0.0001$; WT vs. $\left.\operatorname{rag} 1^{S / S}, p<0.0001\right)$. Developmental progression of DN thymocytes is characterized by an ordered sequence of expression of 

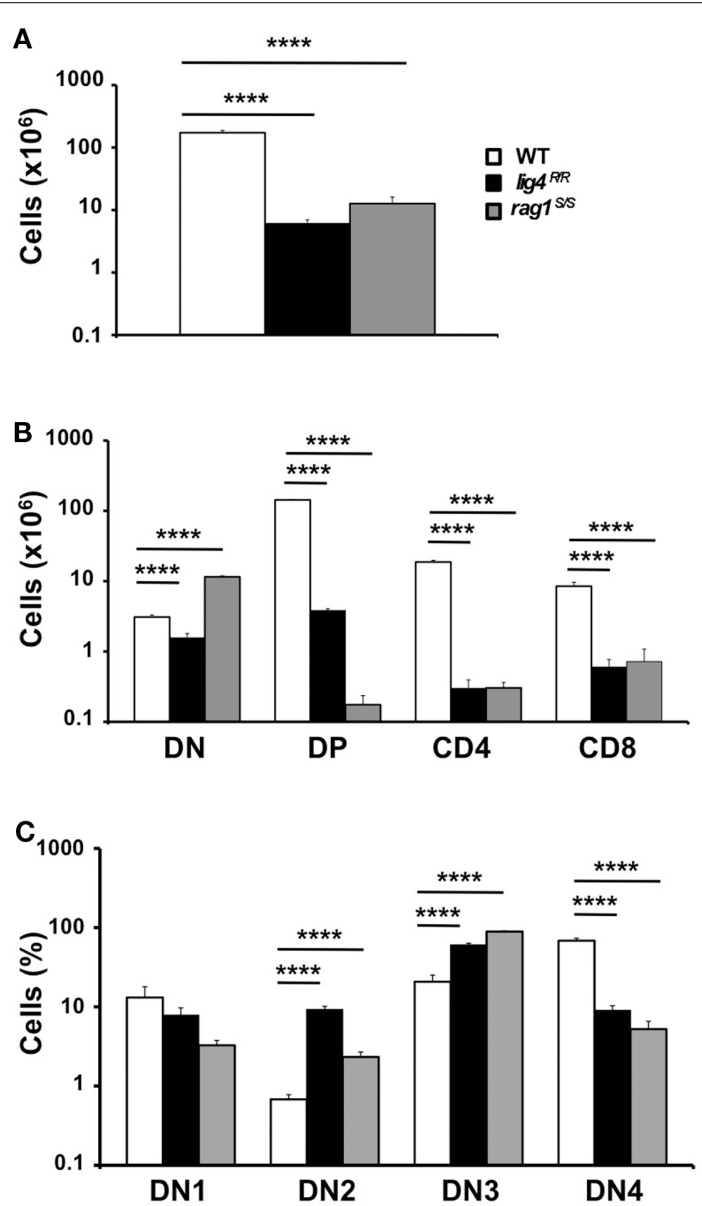

FIGURE 1 |Thymic lymphopenia and impaired T cell development in $\operatorname{lig} 4^{R / R}$ and $\operatorname{rag}^{\text {s/s }}$ mice. (A) Total thymic cellularity from 4 to 5 -weeks-old mice shows severe lymphopenia in lig $4^{R / R}$ and $r a g 1^{S / S}$ mice as compared to WT littermate controls. (B) Thymuses from 4 to 5 -weeks-old mice were stained with anti-CD4 and anti-CD8 antibodies and the absolute numbers of live thymocytes at different stages of differentiation are shown in the bar charts (DN, double negative; DP, double positive). (C) Distribution of CD4CD8 ${ }^{-}$DN thymocytes at various stages of differentiation (DN1-DN4). Mean values \pm SE are shown. At least six mice per group were analyzed.

CD44 and CD25 markers: CD44 ${ }^{+}$CD25- (DN1), CD $44^{+} \mathrm{CD} 25^{+}$ (DN2), CD44- ${ }^{-} \mathrm{CD} 25^{+}$(DN3), CD44- CD25- (DN4). Analysis of the distribution of DN thymocytes in $\operatorname{lig} 4^{R / R}$ and $\mathrm{rag} 1^{\mathrm{S} / S}$ mice revealed a severe, but incomplete arrest of thymocyte development at DN3 stage in both models, consistent with a defect in $\operatorname{TCR} \beta$ rearrangement due to impaired $\mathrm{V}(\mathrm{D}) \mathrm{J}$ recombination (Figure 1C).

\section{SKEWED DISTRIBUTION OF SP T CELLS AND RESTRICTED T CELL REPERTOIRE IN THE THYMUS OF lig4 ${ }^{\mathrm{R} / \mathrm{R}}$ AND $\mathrm{rag}^{\mathrm{S} / \mathrm{S}}$ MICE}

Newly generated $\mathrm{CD}^{+}$and $\mathrm{CD}^{+}$SP thymocytes undergo sequential stages of maturation in the medulla. The developmental program of maturing SP thymocytes is associated with progressive down-regulation of CD69 and up-regulation of the Qa2 markers on the cell surface (Lucas et al., 1994; Jin et al., 2008).The earliest stages in SP cell development (SP1-SP2) are characterized by expression of CD69 but lack of Qa2 marker $\left(\mathrm{CD} 69^{+} \mathrm{Qa}^{-}\right.$ cells). The next step of maturation of SP thymocytes (SP3 stage) is marked by lack of expression of either marker $\left(\mathrm{CD} 9^{-} \mathrm{Qa}^{-}\right.$ cells). Finally, in the last stage of differentiation (SP4), mature SP thymocytes acquire expression of Qa2, and hence have a CD69$\mathrm{Qa}^{+}$phenotype. Thymocytes that reach this stage are ready to egress from the thymus (Ge and Chen, 1999; Jin et al., 2008). In control mice, the majority of $\mathrm{CD}^{+}{ }^{+} \mathrm{SP}$ thymocytes are in the SP1$\mathrm{SP} 2$ stages of differentiation; in contrast, both $\operatorname{lig} 4^{R / R}$ and $\mathrm{rag} 1^{\mathrm{S} / \mathrm{S}}$ mice showed a significant increase in the proportion of $\mathrm{CD} 4^{+} \mathrm{SP}$ thymocytes with the most mature (SP4) phenotype (Figure 2). A similar pattern was observed for $\mathrm{CD}^{+}$SP thymocytes (data not shown).This difference in the distribution of SP thymocytes at various stages of differentiation may reflect several, non-mutually exclusive mechanisms, including accelerated intrathymic $\mathrm{T}$ cell maturation, homeostatic $\mathrm{T}$ cell proliferation in a lymphopenic environment (Datta and Sarvetnick, 2009) and recirculation of mature $\mathrm{T}$ lymphocytes that home back to thymus. In order to distinguish between these possibilities, we have analyzed the distribution of SP thymocytes at late stages ( $18 \pm 2$ days) of fetal development, when homeostatic proliferation and recirculation of mature lymphocytes should not prevail. As shown in Figure A1 in Appendix, even at this stage of fetal development, SP thymocytes from lig4 $4^{R / R}$ and $\mathrm{ragl}^{S / S}$ mice were characterized by a more mature (SP3) phenotype than SP thymocytes from age-matched WT mice. Overall, these data indicate that intra thymic maturation of SP thymocytes is accelerated in $\operatorname{lig} 4^{R / R}$ and $\mathrm{rag} 1^{S / S}$ mice.

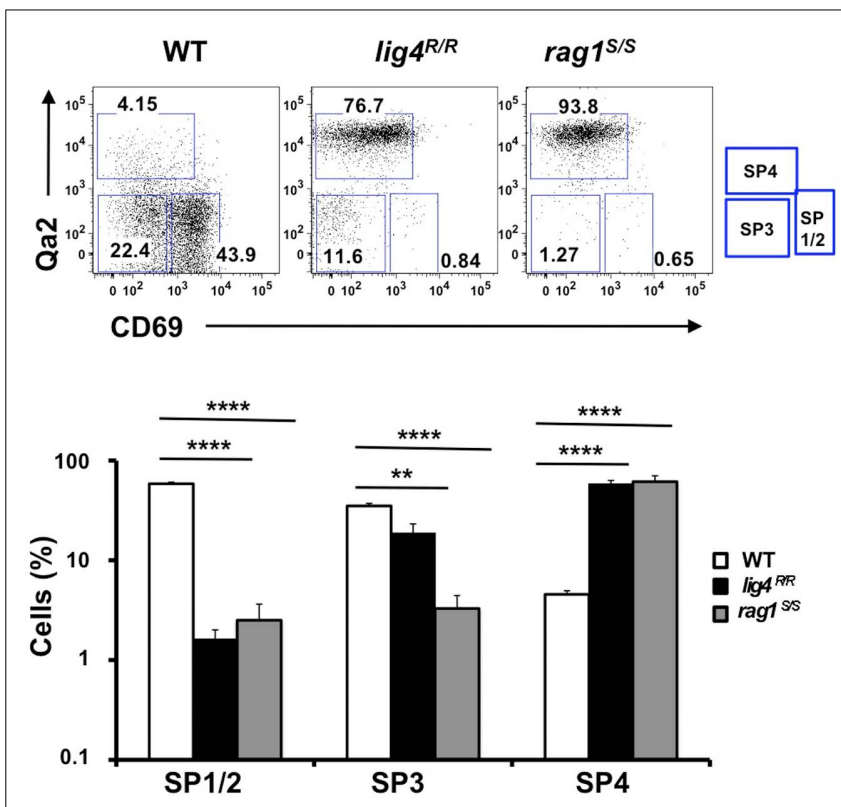

FIGURE 2 |Altered maturation of $\mathrm{CD4}^{+}$SP medullary thymocytes in the $\operatorname{lig} 4^{R / R}$ and $\operatorname{rag~}^{\text {s/s }}$ mice. Upper panels: Representative FACS plots of $\mathrm{CD}^{+} \mathrm{SP}$ medullary thymocytes at various stages of maturation according to the expression of CD69 and Qa2 surface markers. Lower panels: Distribution of the different populations of SP1-SP4 cells. lig ${ }^{R / R}$ and $\mathrm{rag} 1^{\mathrm{S} / \mathrm{S}}$ mice have a significant accumulation of SP4 thymocytes. Mean values $\pm \mathrm{SE}$ are shown. At least six mice per group were analyzed. 
Hypomorphic mutations that affect $\mathrm{V}(\mathrm{D}) \mathrm{J}$ recombination may affect not only the number, but also the TCR repertoire diversity of newly generated thymocytes. We have previously demonstrated that hypomorphic $R A G$ mutations in patients with OS are associated with oligoclonal representation of TCR specificities in the thymus (Signorini et al., 1999). Similarly, a highly restricted T cell repertoire was demonstrated in the thymus of $\mathrm{rag}^{\mathrm{S} / \mathrm{S}}$ mice (Figure 3). In contrast, homozygosity for the $\mathrm{R} 278 \mathrm{H}$ lig4 mutation allowed generation of a broadly polyclonal repertoire of thymocytes (Figure 3). These differences in size and diversity of the thymocyte pool prompted us to investigate thymus morphology in $\operatorname{lig} 4^{R / R}$ and $\mathrm{rag}^{\mathrm{S} / S}$ mice.

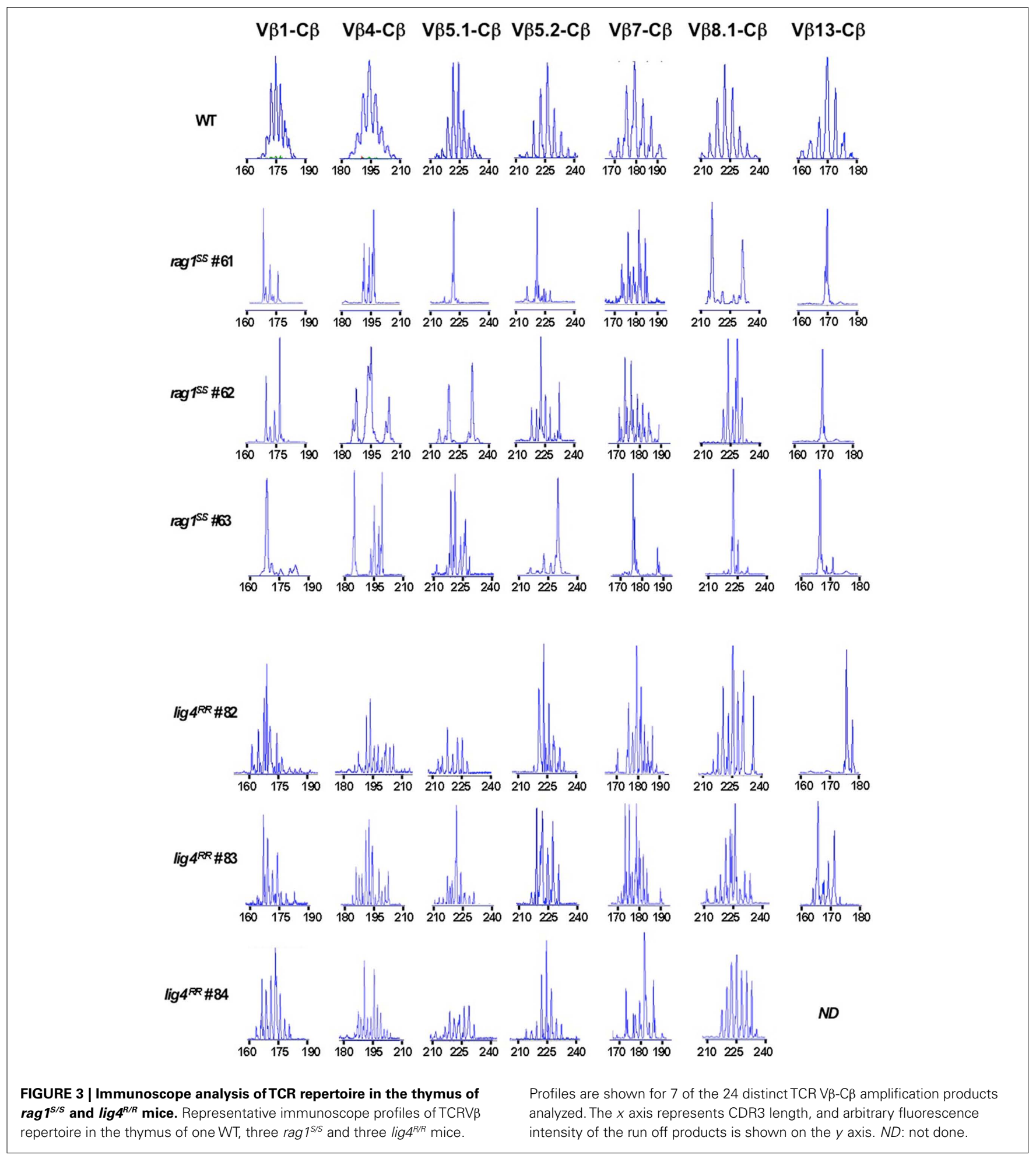




\section{ABNORMALITIES OF THYMIC ARCHITECTURE IN lig4 ${ }^{\mathrm{R} / \mathrm{R}}$ AND $\operatorname{rag}^{\text {S/S }}$ MICE}

Appropriate interaction between elements of the $\mathrm{T}$ cell lineage and stromal cells is crucial to maintain thymic architecture and to support the maturation of both TECs and nascent thymocytes. Severe and early blocks in T cell development are associated with lack of thymic cortico-medullary demarcation (Holländer et al., 1995a). Furthermore, inability to maintain an organized thymic architecture may interfere not only with an orderly maturation of thymocytes, but may also impede establishment of self-tolerance (Holländer et al., 1995b; Derbinski and Kyewski, 2005).

Based on this, we investigated in detail the thymic architecture of lig $4^{R / R}$ and $\mathrm{ragl}^{S / S}$ mice. As shown in Figure 4, staining of thymic tissue with $\mathrm{H} \& \mathrm{E}$ revealed severe depletion of cellularity in both $\operatorname{lig} 4^{R / R}$ and $\mathrm{rag} 1^{S / S}$ mice. Cortico-medullary demarcation was preserved in lig $4^{R / R}$ mice, whereas only a rudimentary attempt to form a medulla was noticed in $\mathrm{rag} \mathrm{I}^{\mathrm{S} / S}$ mice. Differential expression of cytokeratin 8 (CK8) and cytokeratin 5 (CK5) allows distinction between $\mathrm{CK}^{+}{ }^{+} \mathrm{CK}^{-}{ }^{-}$cTECs and $\mathrm{CK} 8^{-} \mathrm{CK} 5^{+}$mTECs (Bennett et al., 2002; Takahama, 2006). Analysis of CK5 and CK8 expression by immunohistochemistry and immunofluorescence confirmed significant differences in the degree of thymic architecture abnormalities in $l i g 4^{R / R}$ and $\mathrm{ragl}^{S / S}$ mice. In particular, only few $\mathrm{CK}^{+}$ cells were detected in $\mathrm{rag} 1^{\mathrm{S} / S}$ mice; furthermore, these cells were largely also $\mathrm{CK}^{+}$, a pattern observed in immature TEC progenitors (Bennett et al., 2002). In contrast, tiny but well-defined nests of $\mathrm{CK}^{+} \mathrm{CK} 8^{-}$mTECs were appreciated in $\operatorname{lig} 4^{R / R}$ mice, consistent with what detected by $\mathrm{H} \& \mathrm{E}$ staining.

\section{ANALYSIS OF MATURATION OF mTECs AND OF AIRE AND TSA EXPRESSION IN THE THYMUS OF lig4 ${ }^{\mathrm{R} / \mathrm{R}}$ AND $\mathrm{rag}^{\mathrm{S} / \mathrm{S}}$ MICE}

The thymic medulla plays an essential role in the tolerance to peripheral antigens. Both mature mTECs and thymic DCs have been implicated in mediating central tolerance by presenting nascent thymocytes with a broad repertoire of TSAs whose expression by mTECs is controlled by the transcription factor Aire (Derbinski et al., 2005; Kyewski and Klein, 2006).
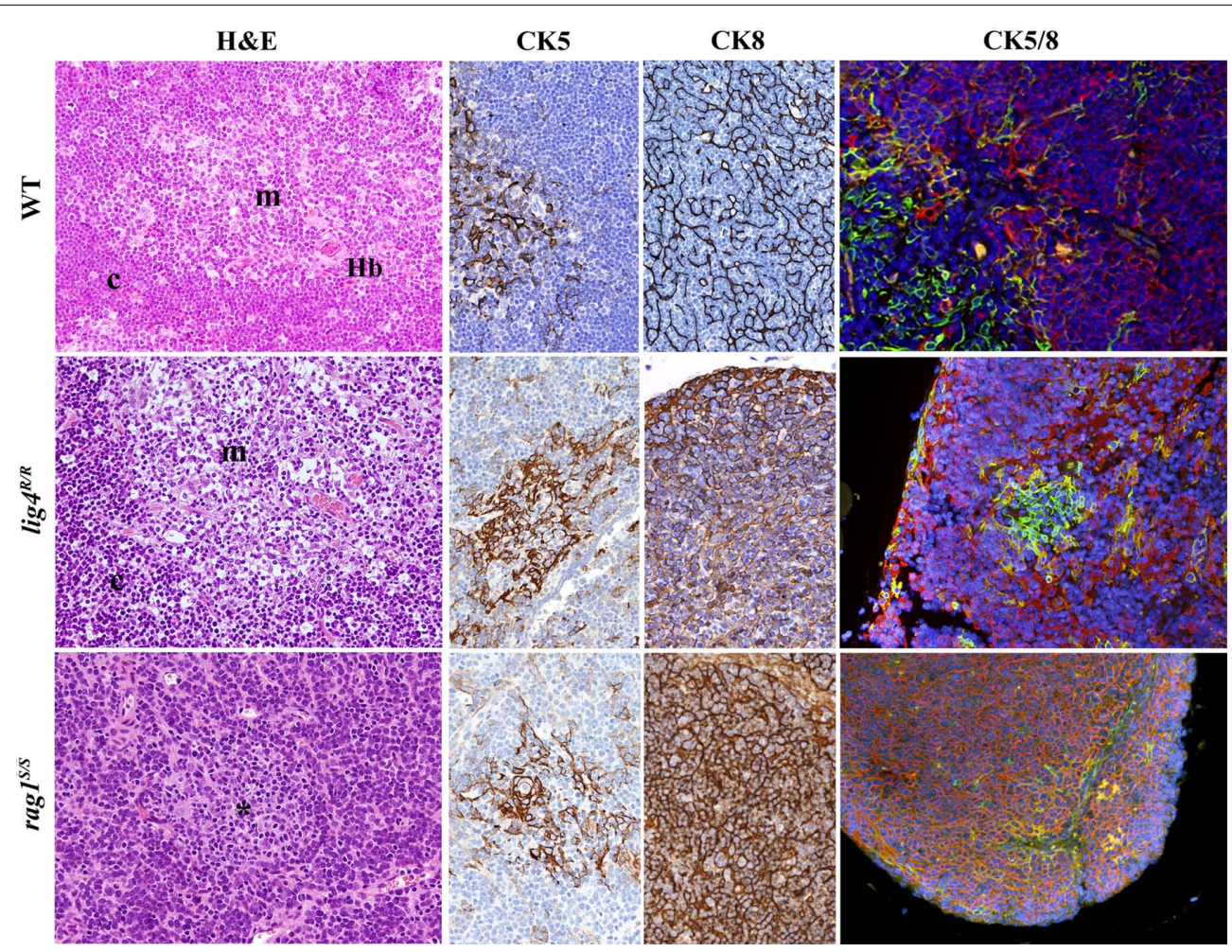

FIGURE 4 | Thymic architecture in wild-type, $\operatorname{lig} 4^{R / R}$, and $\operatorname{rag}^{\mathrm{s} / \mathrm{s}}$ mice. Analysis of thymic architecture and cytokeratin (CK) expression in WT, lig ${ }^{R / R}$, and $\operatorname{rag}^{1 / S}$ mice. Thymic architecture with identification of cortex (c) and medulla $(\mathrm{m})$ is shown in the first column on the left by hematoxylin and eosin ( $\mathrm{H} \& E$ ) staining. The second and third columns show distribution of $\mathrm{CK} 5^{+}$and $\mathrm{CK}^{+}$epithelial cells, respectively. Panels in the right column represent dual immunofluorescence (IF) analysis for $\mathrm{CK}^{+}$(in red) and $\mathrm{CK}^{+}$(in green) cells. Yellow staining identifies cells co-expressing CK5 and CK8. Nuclei are counterstained with DAPI. H\&E staining shows normal cortico-medullary demarcation (CMD) in both WT and lig $4^{R / R}$ mutant mice, whereas only focal areas of medullary differentiation (asterisk) are appreciated in rag $1^{\mathrm{S} / \mathrm{S}}$ mice. A normal distribution of both $\mathrm{CK}^{+}$cells, that represent the vast majority of
mTECs, and $\mathrm{CK}^{+}$cells, that design a fine meshwork of cTECs (upper middle panels, CK5, and CK8 staining), with clear separation between them, is present in WT mice, as shown by IF (upper right panel). Thymuses from lig4//R mutant mice show CMD with normal distribution of the $\mathrm{CK}^{+}$and $\mathrm{CK}^{+}$cells, although the $\mathrm{CK}^{+}$CTECs show a coarse distribution with a globular morphology (middle panels). A well-defined, but tiny thymic medulla is

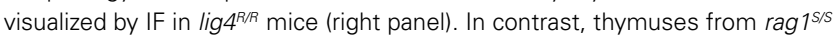
mice show impaired $C M D$ (H\&E, left panel); staining for CKs shows diffuse expression of CK8, and focal expression of CK5 (middle panels). IF shows increased presence of $\mathrm{CK}^{+} \mathrm{CK}^{+}$double positive immature TECs in rag $1^{\mathrm{S} / \mathrm{s}}$ mice (right panel). All panels are from $20 \times$ original magnification. One representative example of 5 mice analyzed per each strain. 
Maturation of mTECs is progressively marked by the expression of claudin-4 (Cld4) and the ligand for UEA-1. Furthermore, terminally differentiated mTECs express high levels of MHC-II molecules and a subset of them also express the transcription factor Aire and TSAs (Hamazaki et al., 2007). Residual presence of $\mathrm{Cld} 4^{+}$and of UEA- ${ }^{+}$mature mTECs was detected in the thymus of $\operatorname{lig} 4^{R / R}$ mice; in contrast, there was no expression of these markers in the thymus from $\mathrm{rag} 1^{S / S}$ mice, in keeping with our previous observations that they lack a well-defined thymic medulla (Figure 5). Staining with anti-Aire antibody revealed a relative abundance of Aire ${ }^{+}$cells in the thymic medulla of WT mice. Aire ${ }^{+}$ cells were detected also in lig $4^{R / R}$ mice, albeit in low number; in contrast, dramatic depletion of Aire ${ }^{+}$cells, that were confined to focal areas of cortico-medullary demarcation, was demonstrated in $\mathrm{rag} 1^{\mathrm{S} / S}$ mice (Figure 5).

Next, we used quantitative real-time polymerase chain reaction (qPCR) to analyze the levels of mRNA specific for Aire and for Aire-dependent TSAs (insulin, cytochrome p450, and fatty acid binding protein) in the thymus of WT, $\operatorname{lig} 4^{R / R}$, and $\mathrm{rag} 1^{S / S}$ mice. A significant reduction in the level of these transcripts was observed in the thymus of both mutant mice; this reduction was particularly pronounced in $\mathrm{rag}^{\mathrm{S} / S}$ mice (Figure 6A).

The observed reduction of Aire and TSA mRNA expression in the thymus of $\operatorname{lig} 4^{R / R}$ and $\mathrm{rag} 1^{S / S}$ mice could reflect either impairment of terminal maturation of mTECs or a general depletion of the mTEC compartment. To distinguish between these two possibilities, we used flow cytometry. It has been shown that cTECs and mTECs can be distinguished based on the expression of MHC-II and Ly-51 markers within the CD45- population of thymic stromal cells (Hubert et al., 2008). Both cTECs and mTECs express MHC-II, but only cTECs express Ly51. Furthermore, based on the levels of expression of MHC-II, it is also possible to discriminate between immature (MHC-II ${ }^{\text {low }}$ Ly$51^{-}$)and mature MHC-II ${ }^{\text {hi }}$ Ly-51- mTECs. Upon staining of CD45- thymic stromal cells for Ly-51 and MHC-II, we found that the thymuses of both $\operatorname{lig} 4^{R / R}$ and $\mathrm{rag} 1^{S / S}$ mice were significantly depleted of mature mTECs (\% MHC-II ${ }^{\text {hi }}$ mTECs \pm SE: $\mathrm{WT}=2.87 \pm 0.8 ; \operatorname{lig} 4^{R / R}=1.12 \pm 0.4 ; \mathrm{rag}^{S / S}=0.17 \pm 0.04 ; \mathrm{WT}$ vs. $\operatorname{lig} 4^{R / R} p<0.005$; WT vs. $\left.\operatorname{rag} 1^{S / S}, p<0.005\right)$. In contrast, both $\operatorname{lig} 4^{R / R}$ and $\mathrm{rag} 1^{S / S}$ mice showed a relative enrichment in thymic cTECs (\% cTECs \pm SE: WT $=19.49 \pm 3.31$; $\operatorname{lig} 4^{R / R}=34.36 \pm 2.92 ; \operatorname{rag} 1^{S / S}=33.51 \pm 2.23 ; \mathrm{WT}$ vs. $\operatorname{lig} 4^{R / R}$, $p<0.005$; WT vs. $\operatorname{ragl}^{S / S}, p<0.005$; Figure 6B). However, this apparent enrichment in cTECs may also reflect the increased number of immature TECs (as demonstrated by co-expression of CK5 and CK8) and/or an increase in fibroblasts or other stromal CD45 Ly $51^{+}$cells, as reported in other murine models of impaired $\mathrm{T}$ cell development (Gray et al., 2002; Rodewald, 2008; Alves et al., 2009).

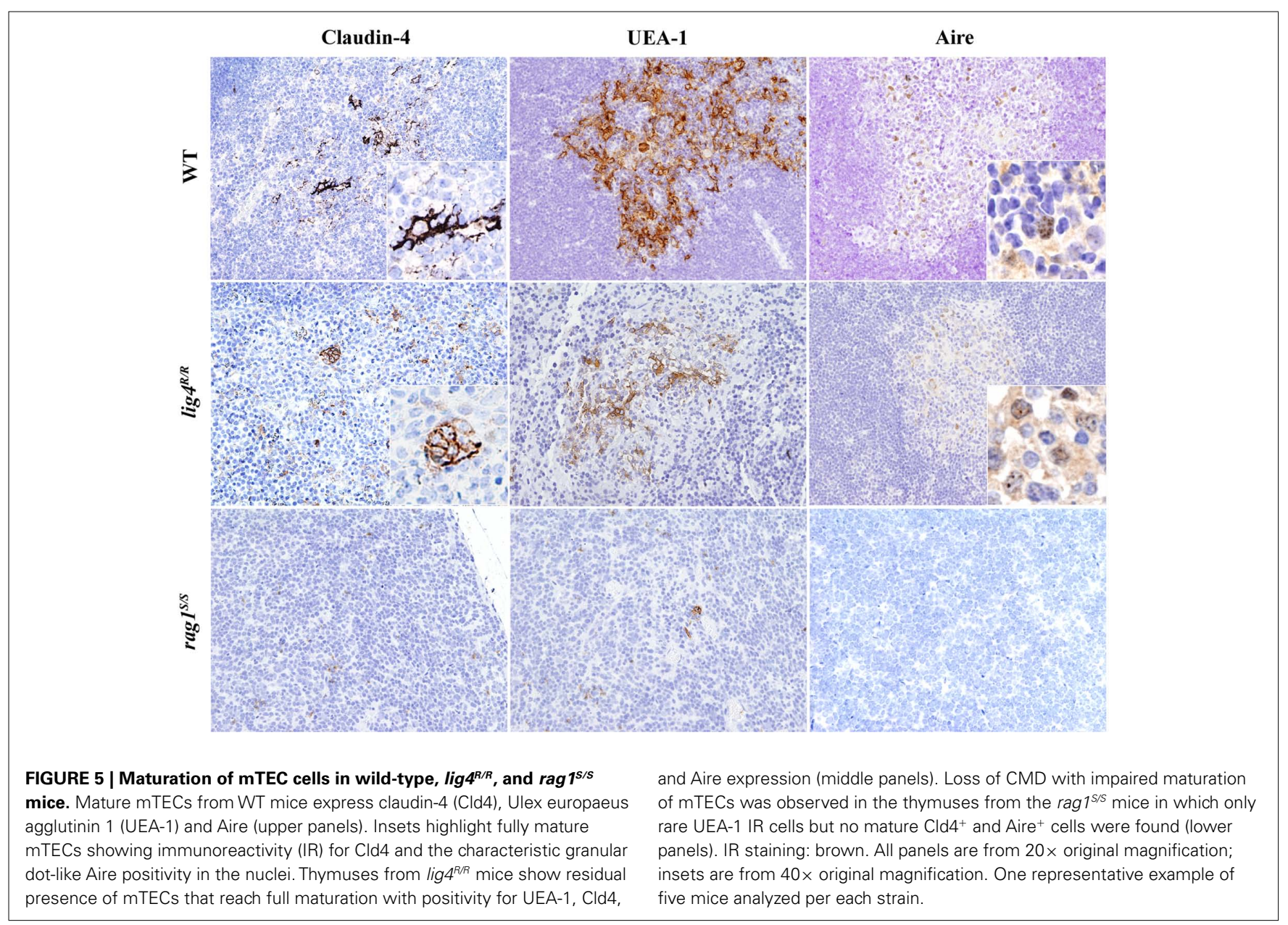




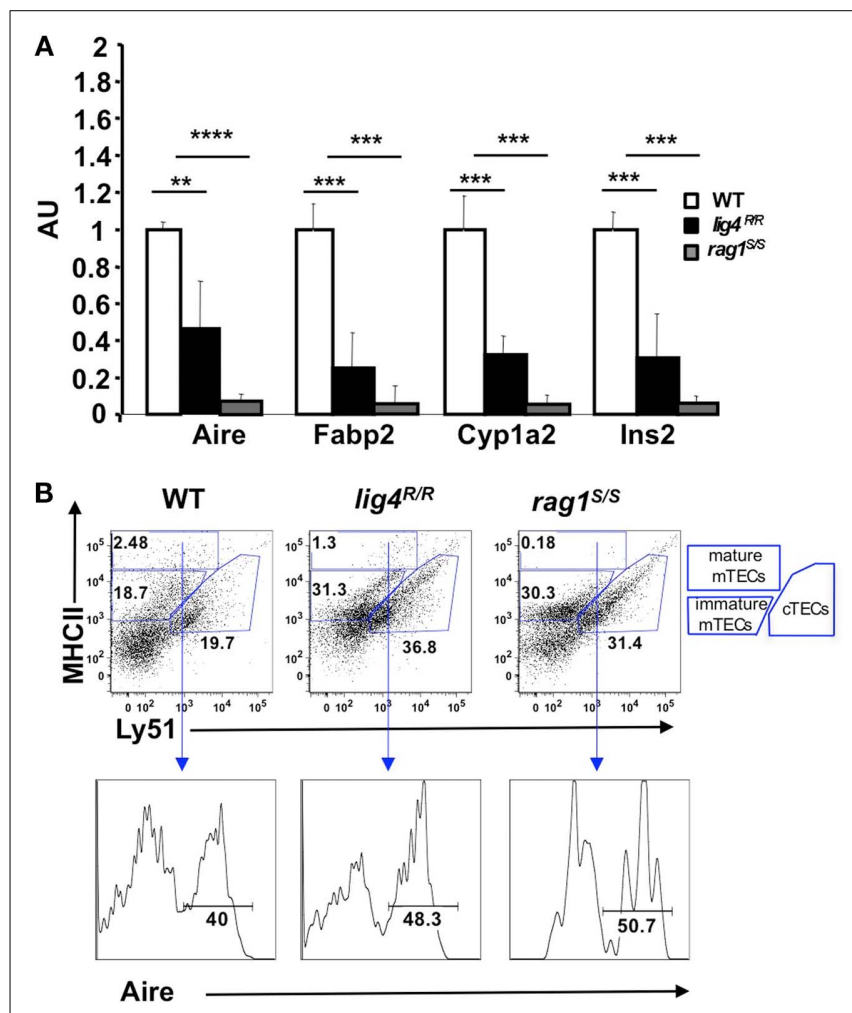

FIGURE 6 | Reduced expression of Aire and of tissue-specific antigens (TSAs) in the thymus of lig $4^{\mathrm{R} / \mathrm{R}}$ and $\mathrm{rag}^{\mathrm{s} / \mathrm{s}}$ mice. (A) Reduced expression of Aire and TSAs (fatty acid binding protein, Fabp2; cytochrome p450, Cyp1a2; insulin 2, Ins2) in the thymus of lig4 $4^{R / /}$ and rag $1^{5 / 5}$ mice. Real time PCR results were normalized to the pan-epithelial marker EpCAM1. Mean values $\pm S D$ are shown. Seven mice per group were analyzed; $A U$, arbitrary units. (B) Representative example of flow cytometry analysis of

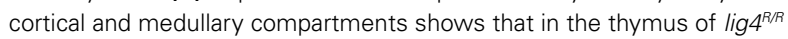
and $\mathrm{rag}^{1 / 5}$ mice the mature medullary compartment (MHC-I $\mathrm{I}^{\text {hi }}$ ) is poorly represented. The percentage of Aire ${ }^{+}$cells among mature mTECs is largely preserved in both mutant mice. At least five mice per group were analyzed.

As mentioned above, fully mature MHC-II ${ }^{\text {hi }}$ mTECs are enriched for Aire expressing cells.In spite of the general reduction in the proportion of mature mTECs, we found that the few $\mathrm{CD} 45^{-}$ MHC-II ${ }^{\text {hi }}$ Ly51 $1^{\text {low }}$ mTECs from $\operatorname{lig} 4^{R / R}$ and $\mathrm{rag} 1^{\mathrm{S} / S}$ mice retained the ability to express Aire $\left(\%\right.$ Aire $^{+}$cells \pm SE: $\mathrm{WT}=43.05 \pm 2.45$; $\operatorname{lig} 4^{R / R}=48.12 \pm 5.11 ; \mathrm{rag} 1^{S / S}=47.05 \pm 5.4$; Figure 6B), indicating that the overall impairment of Aire and TSA expression in these mutant models is due to a reduction of the pool of mature mTECs rather than to intrinsic defects in their developmental and gene expression program.

\section{ANALYSIS OF THYMIC DCs AND GENERATION OF nTreg CELLS IN $\operatorname{lig} 4^{\mathrm{R} / \mathrm{R}}$ AND rag1 $^{\mathrm{S} / \mathrm{s}}$ MICE}

Thymic DCs are the other population of APCs involved in the negative selection of self-reactive thymocytes. Furthermore, a role for thymic DCs in the induction of nTreg cells has been suggested both in mice and in humans (Proietto et al., 2008; Doan et al., 2009). Thymic DCs can be classified into two major subsets: the CD11c ${ }^{+}$

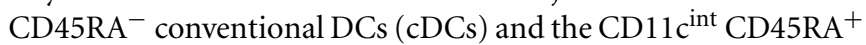
plasmacytoid DCs (pDCs). The first subgroup is intrathymically generated from early thymic progenitor cells, whereas pDCs arise extrathymically from partially differentiated precursors (Proietto et al., 2009).

In order to analyze the distribution of thymic $\mathrm{cDCs}$ and $\mathrm{pDCs}$ in $\mathrm{WT}, \operatorname{lig} 4^{R / R}$, and $\mathrm{rag} 1^{S / S}$ mice, we stained thymic single cells suspensions with a mixture of monoclonal antibodies against markers specific for T and B lymphocytes, erythroid cells, granulocytes, and macrophages (CD3, CD90, CD19, TER119, Gr-1, $\mathrm{CD} 11 \mathrm{~b}$, and F4/80). Upon gating on cells that stained negative for this cocktail of antibodies, we analyzed expression of CD11c and CD45RA to discriminate between cDCs and pDCs. As shown in Figure 7, in WT mice the majority of thymic DCs is composed of cDCs. Although cDCs were more abundant than pDCs also in the thymus of $\operatorname{lig} 4^{R / R}$ and $\mathrm{ragl}^{S / S}$ mice, both mutant strains showed a significant enrichment for pDCs as compared to WT mice (Figure 7).

To investigate whether the profound abnormalities of thymic stroma observed in $\operatorname{lig} 4^{R / R}$ and $\mathrm{rag} 1^{S / S}$ mice could also affect generation of nTreg cells, we analyzed expression of CD25 and Foxp3 within $\mathrm{CD}^{+}$SP thymocytes. As shown in Figure 8, both $\operatorname{lig} 4^{R / R}$ and $\mathrm{rag}^{\mathrm{S} / \mathrm{S}}$ mice showed preserved ability to express Foxp3 within $\mathrm{CD}^{+}{ }^{+} \mathrm{SP}$ thymocytes, and the proportion of Foxp $3^{+}$cells was actually increased in $\operatorname{lig} 4^{R / R}$ mice $\left(\%\right.$ Foxp $3^{+}$cells $\pm \mathrm{SD}$ : $\mathrm{WT}=4.72 \pm 1.3 ; \operatorname{lig} 4^{R / R}=24.2 \pm 3.5 ; \mathrm{rag}^{\mathrm{S} / \mathrm{S}}=6.25 \pm 3.3 ; \mathrm{WT}$ vs. lig4 $4^{R / R} p<0.0001$; WT vs. ragl $^{S / S} p<0.0001$; Figure 8). However, it should be noted that both mutant strains display a severe depletion of thymic cellularity, and of $\mathrm{CD}^{+} \mathrm{SP} \mathrm{T}$ cells in particular (Figure 1). This has obvious implications also on the absolute number of nTreg cells, in particular in $\operatorname{lig} 4^{R / R}$ mice. By
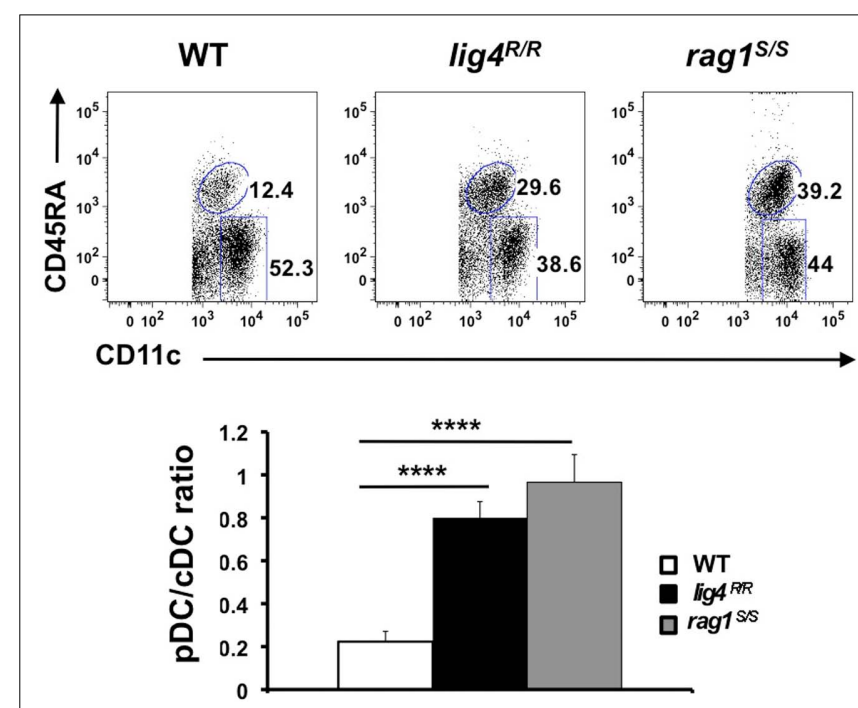

FIGURE 7 | Altered distribution of thymic DCs populations in lig4 $4^{R / R}$ and $\mathbf{r a g}^{\mathrm{s} / \mathrm{s}}$ thymuses. Top panels: FACS dot plot analysis of the distribution of $C D 11 c^{+}$CD45RA- $c D C s$ and $C D 11 c^{\text {int }} C D 45 R A^{\text {hi }} p D C s$ in the thymus of WT, lig4 $4^{R / R}$, and rag $1^{5 / S}$ mice after gating on a population of stromal cells positive for CD11c expression but negative for a cocktail of biotinylated markers specific for markers of $\mathrm{T}$ and $\mathrm{B}$ lymphocytes, erythroid, granulocyte, and macrophage lineages. Lower panels: Proportion of thymic

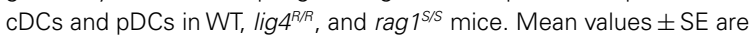
shown. At least six mice per group were analyzed. 


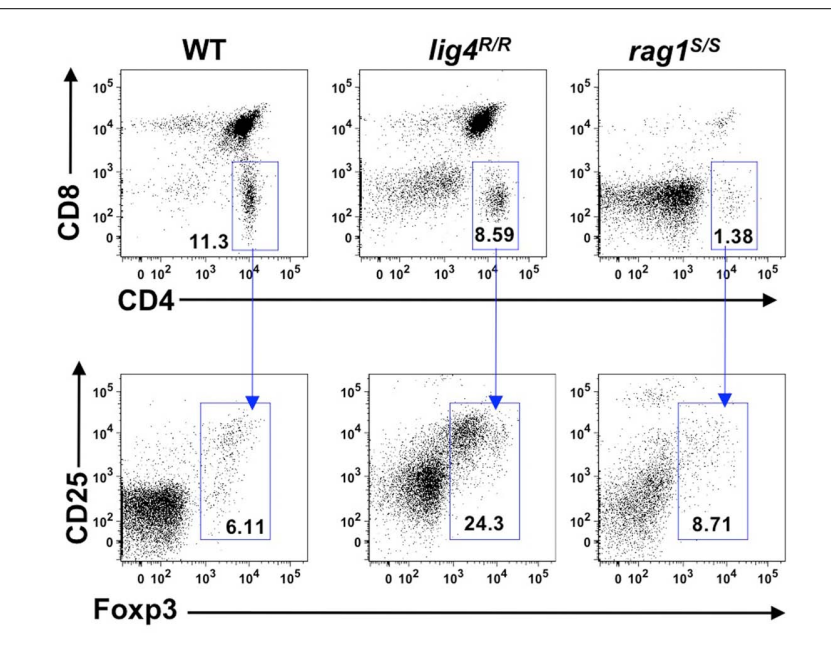

FIGURE 8 | Generation of $n$ Tregs in the thymus of $\operatorname{lig} 4^{R / R}$ and rag $^{S / s}$ mice. Representative example of flow cytometry analysis of thymocytes stained with anti-CD4, anti-CD8, anti-CD25, and anti-Foxp3 antibodies revealed that generation of $n$ Tregs is preserved in the thymus of 4 to 5-weeks-old lig $4^{R / R}$ and $\mathrm{rag}^{\mathrm{S} / \mathrm{S}}$ mice as compared to what observed in WT age-matched littermates. At least six mice per group were analyzed.

using immunohistochemistry, we found that a residual number of Foxp $3^{+}$cells at the cortico-medullary junction were present in $\operatorname{lig} 4^{R / R}$ mice, whereas such cells were severely depleted in $\mathrm{rag}_{1} \mathrm{~S} / \mathrm{S}$ mice (data not shown).

\section{DISCUSSION}

There is growing evidence that defects of $\mathrm{V}(\mathrm{D}) \mathrm{J}$ recombination in humans are associated with a variety of clinical and immunological phenotypes. Null mutations in the $R A G$ genes cause $\mathrm{T}^{-}$ $\mathrm{B}^{-} \mathrm{NK}^{+}$SCID (Schwarz et al., 1996). In contrast, hypomorphic mutations in $R A G$ have been associated with OS (Villa et al., 1998), atypical/leaky SCID (Villa et al., 2001), combined immunodeficiency with expansion of TCR $\gamma \delta^{+}$T cells (Ehl et al., 2005), and delayed-onset combined immunodeficiency with granuloma formation (Schuetz et al., 2008; De Ravin et al., 2010). Extreme phenotypic variability has been observed also among patients with LIG4 syndrome, ranging from mild or moderate immunodeficiency to SCID (O'Driscoll et al., 2001; Buck et al., 2006b; Enders et al., 2006; van der Burg et al., 2006). However, only one patient with OS due to LIG4 mutations has been reported (Grunebaum et al., 2008).

The clinical phenotype of patients carrying hypomorphic mutations that affect $\mathrm{V}(\mathrm{D}) \mathrm{J}$ recombination is often characterized by prominent signs of immune dysregulation, as exemplified by infiltration of target organs by activated and oligoclonal Tymphocytes in patients with OS (Signorini et al., 1999) and by the frequent occurrence of autoantibodies in patients with OS or leaky SCID (Walter et al., 2010). Characterization of the molecular and cellular mechanisms that are responsible for the unique association of severe immunodeficiency and autoimmunity has been hampered by lack of adequate animal models.

We have previously shown that $\operatorname{lig} 4^{R / R}$ and $\mathrm{ragl}^{\mathrm{S} / \mathrm{S}}$ mice represent mouse models of leaky SCID, with profound immunodeficiency and increased risk of autoimmunity (Rucci et al., 2010; Walter et al., 2010). We have also reported that a proportion of $\mathrm{rag} 1^{S / S}$, but not of lig $4^{R / R}$ mice, show more prominent features of severe immune dysregulation, resembling OS (Giblin et al., 2009; Rucci et al., 2010; Walter et al., 2010). We now show that hypomorphic mutations in ragl and lig4 genes in mice affect both normal development of $\mathrm{T}$ lymphocytes and organization and maturation of thymic stroma, and compromise key mechanisms involved in central tolerance.

Studies in mice had indicated that signals delivered by thymocytes are crucial to induce maturation of cTECs and mTECs from a common precursor and to support maintenance of thymic architecture (Holländer et al., 1995a; van Ewijk et al., 2000; Akiyama et al., 2008; Hikosaka et al., 2008; Irla et al., 2008). On the other hand, cTECs and mTECs play a critical role in generating and shaping the mature $\mathrm{T}$ cell repertoire. In particular, cTECs allow positive selection of thymocytes through a mechanism that involves cTECspecific expression of thymoproteasome components, allowing expression of a unique repertoire of MHC-bound self-peptides (Murata et al., 2007; Gommeaux et al., 2009). Positively selected thymocytes are then screened for the ability to recognize selfpeptide/MHC complexes in the thymic medulla. Expression of Aire by terminally differentiated mTECs allows stochastic expression of TSAs. Newly generated T cells that recognize MHC-self TSAs on the surface of mTECs or of thymic DCs are clonally deleted or diverted to become Foxp ${ }^{+}$nTreg cells (Anderson et al., 2002; Bonasio et al., 2006; Aschenbrenner et al., 2007). Generation of $\mathrm{Aire}^{+}$mTECs depends on RANK- and CD40-mediated signaling, and is driven by cross-talk of mTEC progenitors with lymphoid tissue inducer cells and $\mathrm{CD} 4^{+}$thymocytes, that express RANK ligand (RANKL) and CD40 ligand (CD40L), respectively (Rossi et al., 2007; Akiyama et al., 2008; Irla et al., 2008). While expression of Aire by mTECs is not strictly dependent on completion of thymocyte development, recent observations indicate that in post-natal life the size of the pool of mature mTECs (and hence the number of Aire ${ }^{+}$cells) is regulated by signals delivered by positively selected thymocytes, in particular through activation of the lymphotoxin (LT) $\alpha$-LT $\beta$ R axis (White et al., 2010). Consistent with this, Aire ${ }^{+}$mTECs are present, but in low number, in $Z a p 70^{-/-}$ mice (White et al., 2010), in CD40lg-/- mice (Akiyama et al., 2008), and the size of thymic medulla is significantly decreased in $I A a^{-/-}$ mice (Irla et al., 2008), in which lack of expression of MHC-II impairs positive selection of $\mathrm{CD}^{+}{ }^{+}$thymocytes. Altogether, these data indicate a critical role of positively selected thymocytes, and especially $\mathrm{CD} 4{ }^{+} \mathrm{SP}$ cells, in supporting maturation of mTECs and hence maintenance of efficient mechanisms of negative selection of self-reactive $\mathrm{T}$ cells.

We have previously shown impaired maturation of mTECs and reduced expression of Aire in a variety of human immunodeficiencies that affect $\mathrm{T}$ cell development; importantly, similar defects were present also in thymuses from patients carrying hypomorphic mutations that were partially permissive for $\mathrm{T}$ cell development. We now confirm that also in mice hypomorphic rag1 and lig4 mutations that cause a severe, but incomplete defect in $\mathrm{T}$ cell development, are associated with profound abnormalities of thymic stroma architecture and mTECs maturation. In both models, generation of more mature MHC-II ${ }^{\text {hi }}$ 
mTECs was severely compromised, without affecting the intrinsic ability of mTECs to express Aire. Abnormalities of thymic architecture, with impaired formation of a well-defined thymic medulla, were more prominent in $\mathrm{ragl}^{S / S}$ than in $\operatorname{lig} 4^{R / R}$ mice, consistent with a more severe block in $\mathrm{T}$ cell development in the former, with decreased ability to generate DP thymocytes and a severely restricted thymic TCR repertoire. It is likely that the reduced number of mature mTECs expressing Aire and TSAs may contribute to the increased frequency of manifestations of immune dysregulation in mice and humans with hypomorphic mutations that severely affect T cell development (Cavadini et al., 2005; Marrella et al., 2007; Poliani et al., 2009). We have also shown that SP T cells from $\mathrm{rag} 1^{S / S}$ and $\operatorname{lig} 4^{R / R}$ mice are skewed toward a more mature phenotype.

Little is know about the thymic DC compartment in humans and mice with severe defects in T cell development. Mouse studies showed that approximately $27 \%$ of thymic cDCs and $35 \%$ of thymic pDCs contain IgH gene D-J rearrangements, and express mRNA for CD3 and pre-T $\alpha$ chains (Corcoran et al., 2003), indicating that a fraction of thymic DCs share early steps of development with the lymphoid lineages. Furthermore, it is known that the earliest thymic progenitors (ETPs) in mice also possess myeloid potential (Bell and Bhandoola, 2008). Hale et al. (2004) reported that the number of $\mathrm{CD} 83^{+}$mature DCs is significantly reduced in the thymus from patients with X-linked SCID, possibly reflecting the failure of a common progenitor for $\mathrm{T}$ lymphocytes and DCs, to differentiate in response to $\gamma$ c-dependent signals. We have recently reported that depletion of thymic DCs is not restricted to patients with X-linked SCID, but is common to other genetic conditions with impaired T lymphocyte development (Poliani et al., 2009). In apparent contrast to these human data, we found that both $\mathrm{cDCs}$ and $\mathrm{pDC}$ can be detected in the thymus from $\operatorname{lig} 4^{R / R}$ and $\mathrm{rag} 1^{\mathrm{S} / S}$. Further studies are needed to define the location and the origin (intrathymic vs. peripheral) of DCs within the thymus of the mutant mice. This is particularly important since peripheral immature DCs that home to the thymic medulla and to the cortico-medullary junction have been shown to mediate self-antigen presentation and intrathymic deletion of autoreactive T cell clones (Bonasio et al., 2006).

Finally, a role for cDCs (in particular for the CD8 ${ }^{\text {lo }}$ Sirp- $\alpha^{+}$ fraction) in the induction of murine nTreg cells in the thymic medulla has been demonstrated (Proietto et al., 2008). We have

\section{REFERENCES}

Akiyama, T., Shimo, Y., Yanai, H., Qin, J., Ohshima, D., Maruyama, Y., Asaumi, Y., Kitazawa, J., Takayanagi, H., Penninger, J. M., Matsumoto, M., Nitta, T., Takahama, Y., and Inoue, J. (2008). The tumor necrosis factor family receptors RANK and CD40 cooperatively establish the thymic medullary microenvironment and self-tolerance. Immunity 29, 423-437.

Alves, N. L., Huntington, N. D., Rodewald, H. R., and Di Santo, J. P. (2009). Thymic epithelial cells: the multi-tasking framework of the $\mathrm{T}$

shown that $\mathrm{cDCs}$ are present in the thymus of $\operatorname{lig} 4^{R / R}$ and $\operatorname{rag}^{S / S}$ mice; furthermore, our preliminary data suggest that the proportion of $\mathrm{CD} 8^{\text {lo }}$ Sirp- $\alpha^{+}$within thymic cDCs of lig $4^{R / R}$ mice is preserved (data not shown). Consistent with these findings, CD4 ${ }^{+}$ Foxp $3^{+}$cells were detected in the thymus of $\operatorname{lig} 4^{R / R}$ and $\mathrm{ragl}^{\mathrm{S} / \mathrm{S}}$ mice. Somech et al. (2009) have reported a normal proportion of Foxp $^{+}$regulatory $\mathrm{T}$ cells in the periphery of patients with OS. However, others have shown that perturbed Treg function may contribute to immune dysregulation in these patients (Cassani et al., 2010). Although our data indicate that generation of nTreg cells is preserved in $l i g 4^{R / R}$ and $\mathrm{rag} 1^{\mathrm{S} / S}$ mice, the severe defect in T cell development also accounts for the paucity of thymic Foxp $3^{+}$ $\mathrm{T}$ cells in both models.

\section{CONCLUSION}

In summary, we have shown that hypomorphic defects in $\mathrm{V}(\mathrm{D}) \mathrm{J}$ recombination in mice are associated with abnormalities of lymphoid development and thymic architecture. These defects are more prominent and severe in $\mathrm{rag} 1^{S / S}$ than in $\operatorname{lig} 4^{R / R}$ mice. This may reflect a different degree of impairment in $\mathrm{V}(\mathrm{D}) \mathrm{J}$ recombination activity associated with rag1 $\mathrm{S} 723 \mathrm{C}$ and lig4 $\mathrm{R} 278 \mathrm{H}$ mutations, as also suggested by a higher fraction of DP thymocytes in lig $4^{R / R}$ mice. Homozygosity for null mutations in the lig4 gene is associated with embryonic lethality in mice, and patients with LIG4 mutations identified so far carry a hypomorphic mutation on at least one allele. This may explain why clinical manifestations of immune dysregulation have been more frequently reported among patients with RAG than with LIG4 mutations. Alternatively, it is also possible that the different severity of phenotype may reflect the specific role played by RAG and LIG4 genes. The study of new patients and the development of additional animal models with mutations in these genes may help address this issue.

\section{ACKNOWLEDGMENTS}

We thank Mike Recher, Laura Patrizi, and Divij Matthew for animal care. This work was partially supported by the National Institutes of Health Grant P01 AI076210-01A1 (to Luigi Daniele Notarangelo and Frederick W. Alt), by the Manton Foundation (Luigi Daniele Notarangelo), by Fondazione "Angelo Nocivelli" (Silvia Giliani) and by Fondazione CARIPLO (Pietro Luigi Poliani). Frederick W. Alt is a Howard Hughes Investigator.

Emmerich, J., Swee, L. K., Rolink, A., and Klein, L. (2007). Selection of Foxp3+ regulatory $\mathrm{T}$ cells specific for self antigen expressed and presented by Aire+ medullary thymic epithelial cells. Nat. Immunol. 8, 351-358.

Bell, J. J., and Bhandoola, A. (2008). The earliest thymic progenitors for $\mathrm{T}$ cells possess myeloid lineage potential. Nature 452, 764-767.

Bennett, A. R., Farley, A., Blair, N. F., Gordon, J., Sharp, L., and Blackburn, C. C. (2002). Identification and characterization of thymic epithelial progenitor cells. Immunity 16, 803-814.
Bonasio, R., Scimone, M. L., Schaerli, P., Grabie, N., Lichtman, A. H., and von Andrian, U. H. (2006). Clonal deletion of thymocytes by circulating dendritic cells homing to the thymus. Nat. Immunol. 7, 1092-1100.

Buck, D., Malivert, L., de Chasseval, R., Barraud, A., Fondanèche, M. C., Sanal, O., Plebani, A., Stéphan, J. L., Hufnagel, M., le Deist, F., Fischer, A., Durandy, A., de Villartay, J. P., and Revy, P. (2006a). Cernunnos, a novel nonhomologous end-joining factor, is mutated in human immunodeficiency with microcephaly. Cell 124, 287-299. 
Buck, D., Moshous, D., de Chasseval, R., Ma, Y., le Deist, F., CavazzanaCalvo, M., Fischer, A., Casanova, J. L., Lieber, M. R., and de Villartay, J. P. (2006b). Severe combined immunodeficiency and microcephaly in siblings with hypomorphic mutations in DNA ligase IV. Eur. J. Immunol. 36, 224-235.

Buckley, R. H. (2000). Primary immunodeficiency diseases due to defects in lymphocytes. N. Engl. J. Med. 343, 1313-1324.

Cassani, B., Poliani, P. L., Moratto, D., Sobacchi, C., Marrella, V., Imperatori, L., Vairo, D., Plebani, A., Giliani, S., Vezzoni, P., Facchetti, F., Porta, F., Notarangelo, L. D., Villa, A., and Badolato, R. (2010). Defect of regulatory $\mathrm{T}$ cells in patients with Omenn syndrome. J. Allergy Clin. Immunol. 125, 209-216.

Cavadini, P., Vermi, W., Facchetti, F., Fontana, S., Nagafuchi, S., Mazzolari, E., Sediva, A., Marrella, V., Villa, A., Fischer, A., Notarangelo, L. D., and Badolato, R. (2005). Aire deficiency in thymus of 2 patients with Omenn syndrome. J. Clin. Invest. 115, 728-732.

Corcoran, L., Ferrero, I., Vremec, D., Lucas, K., Waithman, J., O'Keeffe, M., Wu, L., Wilson, A., and Shortman, K. (2003). The lymphoid past of mouse plasmacytoid cells and thymic dendritic cells. J. Immunol. 170, 4926-4932.

Datta, S., and Sarvetnick, N. (2009). Lymphocyte proliferation in immune-mediated diseases. Trends Immunol. 30, 430-438.

De Ravin, S. S., Cowen, E. W., Zarember, K. A., Whiting-Theobald, N. L., Kuhns, D. B., Sandler, N. G., Douek, D. C., Pittaluga, S., Poliani, P. L., Lee, Y. N., Notarangelo, L. D., Wang, L., Alt, F. W., Kang, E. M., Milner, J. D., Niemela, J. E., Fontana-Penn, M., Sinal, S. H., and Malech, H. L. (2010). Hypomorphic Rag mutations can cause destructive midline granulomatous disease. Blood 116, 1263-1271.

Derbinski, J., Gäbler, J., Brors, B., Tierling, S., Jonnakuty, S., Hergenhahn, M., Peltonen, L., Walter, J., and Kyewski, B. (2005). Promiscuous gene expression in thymic epithelial cells is regulated at multiple levels. $J$. Exp. Med. 202, 33-45.

Derbinski, J., and Kyewski, B. (2005). Linking signalling pathways, thymic stroma integrity and autoimmunity. Trends Immunol. 26, 503-506.

Doan, T., McNally, A., Thomas, R., and Steptoe, R. J. (2009). Steady-state dendritic cells continuously inactivate $\mathrm{T}$ cells that escape thymic negative selection. Immunol. Cell Biol. 87, 615-622.

Ehl, S., Schwarz, K., Enders, A., Duffner, U., Pannicke, U., Kühr, J., Mascart, F., Schmitt-Graeff, A., Niemeyer, C., and Fisch, P. (2005). A variant of SCID with specific immune responses and predominance of gamma delta T cells. J. Clin. Invest. 115, 3140-3148.

Enders, A., Fisch, P., Schwarz, K., Duffner, U., Pannicke, U. Nikolopoulos, E., Peters, A., Orlowska-Volk, M., Schindler, D., Friedrich, W., Selle, B., Niemeyer, C., and Ehl, S. (2006). A severe form of human combined immunodeficiency due to mutations in DNA ligase IV. J. Immunol. 176, 5060-5068.

Fischer, A. (2000). Severe combined immunodeficiencies (SCID). Clin. Exp. Immunol. 122, 143-149.

Fischer, A. (2007). Human primary immunodeficiency diseases. Immunity 27, 835-845.

Fugmann, S. D., Lee, A. I., Shockett, P. E., Villey, I. J., and Schatz, D. G. (2000). The RAG proteins and $\mathrm{V}(\mathrm{D}) \mathrm{J}$ recombination: complexes, ends, and transposition. Annu. Rev. Immunol. 18, 495-527.

Ge, Q., and Chen, W. F. (1999). Phenotypic identification of the subgroups of murine $\mathrm{T}$-cell receptor alphabeta+ CD4+ CD8 - thymocytes and its implication in the late stage of thymocyte development. Immunology 97, 665-671.

Gennery, A. R. (2006). Primary immunodeficiency syndromes associated with defective DNA double-strand break repair. Br. Med. Bull. 77-78, 71-85.

Giblin, W., Chatterji, M., Westfield, G., Masud, T., Theisen, B., Cheng, H. L., DeVido, J., Alt, F. W., Ferguson, D. O., Schatz, D. G., and Sekiguchi, J. (2009). Leaky severe combined immunodeficiency and aberrant DNA rearrangements due to a hypomorphic RAG1 mutation. Blood 113, 2965-2975.

Gommeaux, J., Grégoire, C., Nguessan, P., Richelme, M., Malissen, M., Guerder, S., Malissen, B., and Carrier, A. (2009). Thymus-specific serine protease regulates positive selection of a subset of CD4+ thymocytes. Eur. J. Immunol. 39, 956-964.

Gray, D. H., Chidgey, A. P., and Boyd, R. L. (2002). Analysis of thymic stromal cell populations using flow cytometry. J. Immunol. Methods 260, 15-28.

Grunebaum, E., Bates, A., and Roifman, C. M. (2008). Omenn syndrome is associated with mutations in DNA ligase IV. J. Allergy Clin. Immunol. 122, 1219-1220.

Hale, L. P., Buckley, R. H., Puck, J. M., and Patel, D. D. (2004). Abnormal development of thymic dendritic and epithelial cells in human $\mathrm{X}$-linked severe combined immunodeficiency. Clin. Immunol. 110, 6370 .

Hamazaki, Y., Fujita, H., Kobayashi, T., Choi, Y., Scott, H. S., Matsumoto, M., and Minato, N. (2007). Medullary thymic epithelial cells expressing Aire represent a unique lineage derived from cells expressing claudin. Nat. Immunol. 8, 304-311.

Hikosaka, Y., Nitta, T., Ohigashi, I., Yano, K., Ishimaru, N., Hayashi, Y., Matsumoto, M., Matsuo, K., Penninger, J. M., Takayanagi, H., Yokota, Y., Yamada, H., Yoshikai, Y., Inoue, J., Akiyama, T., and Takahama, Y. (2008). The cytokine RANKL produced by positively selected thymocytes fosters medullary thymic epithelial cells that express autoimmune regulator. Immunity 29, 438450.

Hogquist, K. A., Baldwin, T. A., and Jameson, S. C. (2005). Central tolerance: learning self-control in the thymus. Nat. Rev. Immunol. 5, 772782

Holländer, G. A., Wang, B., Nichogiannopoulou, A., Platenburg, P. P., van Ewijk, W., Burakoff, S. J., Gutierrez-Ramos, J. C., and Terhorst, C. (1995a). Developmental control point in induction of thymic cortex regulated by a subpopulation of prothymocytes. Nature 373, 350-353.

Holländer, G. A., Simpson, S. J., Mizoguchi, E., Nichogiannopoulou, A., She, J., Gutierrez-Ramos, J. C., Bhan, A. K., Burakoff, S. J., Wang, B., and Terhorst, C. (1995b). Severe colitis in mice with aberrant thymic selection. Immunity 3 27-38.

Hubert, F. X., Kinkel, S. A., Webster, K. E., Cannon, P., Crewther, P. E., Proeitto, A. I., Wu, L., Heath, W. R., and Scott, H. S. (2008). A specific anti-Aire antibody reveals aire expression is restricted to medullary thymic epithelial cells and not expressed in periphery. J. Immunol. 18, 3824-3832.

Irla, M., Hollander, G., and Reith, W. (2010). Control of central selftolerance induction by autoreactive CD4+ thymocytes. Trends Immunol. 31, 71-79.

Irla, M., Hugues, S., Gill, J., Nitta, T., Hikosaka, Y., Williams, I. R., Hubert,
F. X., Scott, H. S., Takahama, Y., Holländer, G. A., and Reith, W. (2008). Autoantigen-specific interactions with CD4+ thymocytes control mature medullary thymic epithelial cell cellularity. Immunity 29, 451-463.

Jin, R., Wang, W., Yao, J. Y., Zhou, Y. B., Qian, X. P., Zhang, J., Zhang, Y., and Chen, W. F. (2008). Characterization of the in vivo dynamics of medullary CD4+CD8 - thymocyte development. J. Immunol. 180 2256-2263.

Kyewski, B., and Klein, L. (2006). A central role for central tolerance. Annu. Rev. Immunol. 24, 571-606.

Lucas, B., Vasseur, F., and Penit, C. (1994). Production, selection, and maturation of thymocytes with high surface density of TCR. J. Immunol. 153, 53-62.

Marrella, V., Poliani, P. L., Casati, A., Rucci, F., Frascoli, L., Gougeon, M. L., Lemercier, B., Bosticardo, M., Ravanini, M., Battaglia, M., Roncarolo, M. G., Cavazzana-Calvo, M., Facchetti, F., Notarangelo, L. D., Vezzoni, P., Grassi, F., and Villa, A. (2007). A hypomorphic R229Q Rag2 mouse mutant recapitulates human Omenn syndrome. J. Clin. Invest. 117, 1260-1269.

Miyara, M., and Sakaguchi, S. (2007). Natural regulatory $\mathrm{T}$ cells: mechanisms of suppression. Trends. Mol. Med. 13, 108-116.

Moshous, D., Callebaut, I., de Chasseval, R., Corneo, B., Cavazzana-Calvo, M., Le Deist, F., Tezcan, I., Sanal, O., Bertrand, Y., Philippe, N., Fischer, A., and de Villartay, J. P. (2001). Artemis, a novel DNA double-strand break repair/V(D)J recombination protein, is mutated in human severe combined immune deficiency. Cell 105, 177-186.

Murata, S., Sasaki, K., Kishimoto, T., Niwa, S., Hayashi, H., Takahama Y., and Tanaka, K. (2007). Regulation of CD8 + T cell development by thymus-specific proteasomes. Science 316, 1349-1353.

Notarangelo, L. D. (2010). Primary immunodeficiencies. J. Allergy Clin. Immunol. 125, S182-S189.

O'Driscoll, M., Cerosaletti, K. M., Girard, P. M., Dai, Y., Stumm, M., Kysela, B., Hirsch, B., Gennery, A., Palmer, S. E., Seidel, J., Gatti, R. A., Varon, R., Oettinger, M. A., Neitzel, H., Jeggo, P. A., and Concannon, P. (2001). DNA ligase IV mutations identified in patients exhibiting developmental delay and immunodeficiency. Mol. Cell 8, 1175-1185. 
O’Driscoll, M., Gennery, A. R., Seidel, J., Concannon, P., and Jeggo, P. A. (2004). An overview of three new disorders associated with genetic instability: LIG4 syndrome, RS-SCID and ATR-Seckel syndrome. DNA Repair (Amst.) 3, 1227-1235.

Poliani, P. L., Facchetti, F., Ravanini, M., Gennery, A. R., Villa, A., Roifman, C. M., and Notarangelo, L. D. (2009). Early defects in human T-cell development severely affect distribution and maturation of thymic stromal cells: possible implications for the pathophysiology of Omenn syndrome. Blood 114, 105-108.

Proietto, A. I., van Dommelen, S., and $\mathrm{Wu}, \mathrm{L}$. (2009). The impact of circulating dendritic cells on the development and differentiation of thymocytes. Immunol. Cell Biol. 87, 39-45.

Proietto, A. I., van Dommelen. S., Zhou, P., Rizzitelli, A., D’Amico, A., Steptoe, R. J., Naik, S. H., Lahoud, M. H., Liu, Y., Zheng, P., Shortman, K., and Wu, L. (2008). Dendritic cells in the thymus contribute to T-regulatory cell induction. Proc. Natl. Acad. Sci. U.S.A. 105, 19869-19874. [Erratum in: Proc. Natl. Acad. Sci. U.S.A. 2009, 106, 1679].

Riballo, E., Critchlow, S. E., Teo, S. H., Doherty, A. J., Priestley, A., Broughton, B., Kysela, B., Beamish, H., Plowman, N., Arlett, C. F., Lehmann, A. R., Jackson, S. P., and Jeggo, P. A. (1999). Identification of a defect in DNA ligase IV in a radiosensitive leukaemia patient. Curr. Biol. 9, 699-702.

Rodewald, H. R. (2008). Thymus organogenesis. Annu. Rev. Immunol. 26, 355-388.

Rooney, S., Chaudhuri, J., and Alt, F. W. (2004). The role of the nonhomologous end-joining pathway in lymphocyte development. Immunol. Rev. 200, 115-131.

Rossi, S. W., Kim, M. Y., Leibbrandt, A., Parnell, S. M., Jenkinson, W. E., Glanville, S. H., McConnell, F. M., Scott, H. S., Penninger, J. M., Jenkinson, E. J., Lane, P. J., and Anderson, G. (2007). RANK signals from $\mathrm{CD} 4(+) 3(-)$ inducer cells regulate development of Aireexpressing epithelial cells in the thymic medulla. J. Exp. Med. 204, 1267-1272.
Rucci, F., Notarangelo, L. D., Fazeli, A., Patrizi, L., Hickernell, T., Paganini, T., Coakley, K. M., Detre, C., Keszei, M., Walter, J. E., Feldman, L., Cheng, H. L., Poliani, P. L., Wang, J. H., Balter, B. B., Recher, M., Andersson, E. M., Zha, S., Giliani, S., Terhorst, C., Alt, F. W., and Yan, C. T. (2010). Homozygous DNA ligase IV $\mathrm{R} 278 \mathrm{H}$ mutation in mice leads to leaky SCID and represents a model for human LIG4 syndrome. Proc. Natl. Acad. Sci. U.S.A. 107, 3024-3029.

Schuetz, C., Huck, K., Gudowius, S., Megahed, M., Feyen, O., Hubner, B., Schneider, D. T., Manfras, B., Pannicke, U., Willemze, R., Knüchel, R., Göbel, U., Schulz, A., Borkhardt, A., Friedrich, W., Schwarz, K., and Niehues, T. (2008). An immunodeficiency disease with RAG mutations and granulomas. N. Engl. J. Med. 358, 2030-2038.

Schwarz, K., Gauss, G. H., Ludwig, L., Pannicke, U., Li, Z., Lindner, D., Friedrich, W., Seger, R. A., Hansen-Hagge, T. E., Desiderio, S., Lieber, M. R., and Bartram, C. R. (1996). RAG mutations in human B cell-negative SCID. Science 274, 97-99.

Signorini, S., Imberti, L., Pirovano, S., Villa, A., Facchetti, F., Ungari, M., Bozzi, F., Albertini, A., Ugazio, A. G., Vezzoni, P., and Notarangelo, L. D. (1999). Intrathymic restriction and peripheral expansion of the T-cell repertoire in Omenn syndrome. Blood 94, 3468-4378.

Sobacchi, C., Marrella, V., Rucci, F., Vezzoni, P., and Villa, A. (2006). RAG-dependent primary immunodeficiencies. Hum. Mutat. 27, 1174-1184.

Somech, R., Simon, A. J., Lev, A., Dalal, I., Spirer, Z., Goldstein, I., Nagar, M., Amariglio, N., Rechavi, G., and Roifman, C. M. (2009). Reduced central tolerance in Omenn syndrome leads to immature self-reactive oligoclonal T cells. J. Allergy Clin. Immunol. 124, 793-800.

Takahama, Y. (2006). Journey through the thymus: stromal guides for T-cell development and selection. Nat. Rev. Immunol. 6, 127-135.

Takahama, Y., Nitta, T., Mat Ripen, A., Nitta, S., Murata, S., and Tanaka, K. (2010). Role of thymic cortexspecific self-peptides in positive selection of T cells. Semin. Immunol. 22, 287-293.

van der Burg, M., Ijspeert, H., Verkaik, N. S., Turul, T., Wiegant, W. W., Morotomi-Yano, K., Mari, P. O., Tezcan, I., Chen, D. J., Zdzienicka, M. Z., van Dongen, J. J., and van Gent, D. C. (2009). A DNAPKcs mutation in a radiosensitive T-B-SCID patient inhibits Artemis activation and non-homologous end-joining. J. Clin. Invest. 119 91-98.

van der Burg, M., van Veelen, L. R., Verkaik, N. S., Wiegant, W. W., Hartwig, N. G., Barendregt, B. H., Brugmans, L., Raams, A., Jaspers, N. G., Zdzienicka, M. Z., van Dongen, J. J., and van Gent, D. C. (2006). A new type of radiosensitive T-B-NK+ severe combined immunodeficiency caused by a LIG4 mutation. J. Clin. Invest. 116, 137-145.

van Ewijk, W., Holländer, G., Terhorst, C., and Wang, B. (2000). Stepwise development of thymic microenvironments in vivo is regulated by thymocyte subsets. Development 127 , 1583-1591.

Villa, A., Santagata, S., Bozzi, F., Giliani, S., Frattini, A., Imberti, L., Gatta, L. B., Ochs, H. D., Schwarz, K., Notarangelo, L. D., Vezzoni, P., and Spanopoulou, E. (1998). Partial $\mathrm{V}(\mathrm{D}) \mathrm{J}$ recombination activity leads to Omenn syndrome. Cell 93, 885896.

Villa, A., Sobacchi, C., Notarangelo, L. D., Bozzi, F., Abinun, M., Abrahamsen, T. G., Arkwright, P. D., Baniyash, M., Brooks, E. G., Conley, M. E., Cortes, P., Duse, M., Fasth, A., Filipovich, A. M., Infante, A. J., Jones, A., Mazzolari, E., Muller, S. M., Pasic, S., Rechavi, G., Sacco, M. G., Santagata, S., Schroeder, M. L., Seger, R., Strina, D., Ugazio, A., Väliaho, J., Vihinen, M., Vogler, L. B., Ochs, H., Vezzoni, P., Friedrich, W., and Schwarz, K. (2001). V(D)J recombination defects in lymphocytes due to RAG mutations: severe immunodeficiency with a spectrum of clinical presentations. Blood 97, 81-88.

Walter, J. E., Rucci, F., Patrizi, L., Recher, M., Regenass, S., Paganini, T., Keszei, M., Pessach, I., Lang, P. A., Poliani, P. L., Giliani, S., Al-Herz, W., Cowan, M. J., Puck, J. M., Bleesing, J., Niehues. T., Schuetz, C., Malech, H.,
DeRavin, S. S., Facchetti, F., Gennery, A. R., Andersson, E., Kamani, N. R., Sekiguchi, J., Alenezi, H. M., Chinen, J., Dbaibo, G., ElGhazali, G., Fontana, A., Pasic, S., Detre, C., Terhorst, C., Alt, F. W., and Notarangelo, L. D. (2010). Expansion of immunoglobulin-secreting cells and defects in B cell tolerance in Rag-dependent immunodeficiency. J. Exp. Med. 207, 1541-1554.

Watanabe, N., Wang, Y. H., Lee, H. K., Ito, T., Wang, Y. H., Cao, W. and Liu, Y. J. (2005). Hassall's corpuscles instruct dendritic cells to induce $\mathrm{CD} 4+\mathrm{CD} 25+$ regulatory $\mathrm{T}$ cells in human thymus. Nature 436, 1181-1185.

White, A. J., Nakamura, K., Jenkinson, W. E., Saini, M., Sinclair, C., Seddon, B., Narendran, P., Pfeffer, K., Nitta, T., Takahama, Y., Caamano, J. H., Lane, P. J., Jenkinson, E. J., and Anderson, G. (2010). Lymphotoxin signals from positively selected thymocytes regulate the terminal differentiation of medullary thymic epithelial cells. J. Immunol. 185, 4769-4776.

Conflict of Interest Statement: The authors declare that the research was conducted in the absence of any commercial or financial relationships that could be construed as a potential conflict of interest.

Received: 14 February 2011; accepted: 01 May 2011; published online: 11 May 2011.

Citation: Rucci F, Poliani PL, Caraffi S, Paganini T, Fontana E, Giliani S, Alt FW and Notarangelo LD (2011) Abnormalities of thymic stroma may contribute to immune dysregulation in murine models of leaky severe combined immunodeficiency. Front. Immun. 2:15. doi: 10.3389/fimmu.2011.00015

This article was submitted to Frontiers in Primary Immunodeficiencies, a specialty of Frontiers in Immunology.

Copyright (C) 2011 Rucci, Poliani, Caraffi, Paganini, Fontana, Giliani, Alt and Notarangelo. This is an open-access article subject to a non-exclusive license between the authors and Frontiers Media SA, which permits use, distribution and reproduction in other forums, provided the original authors and source are credited and other Frontiers conditions are complied with. 


\section{APPENDIX}

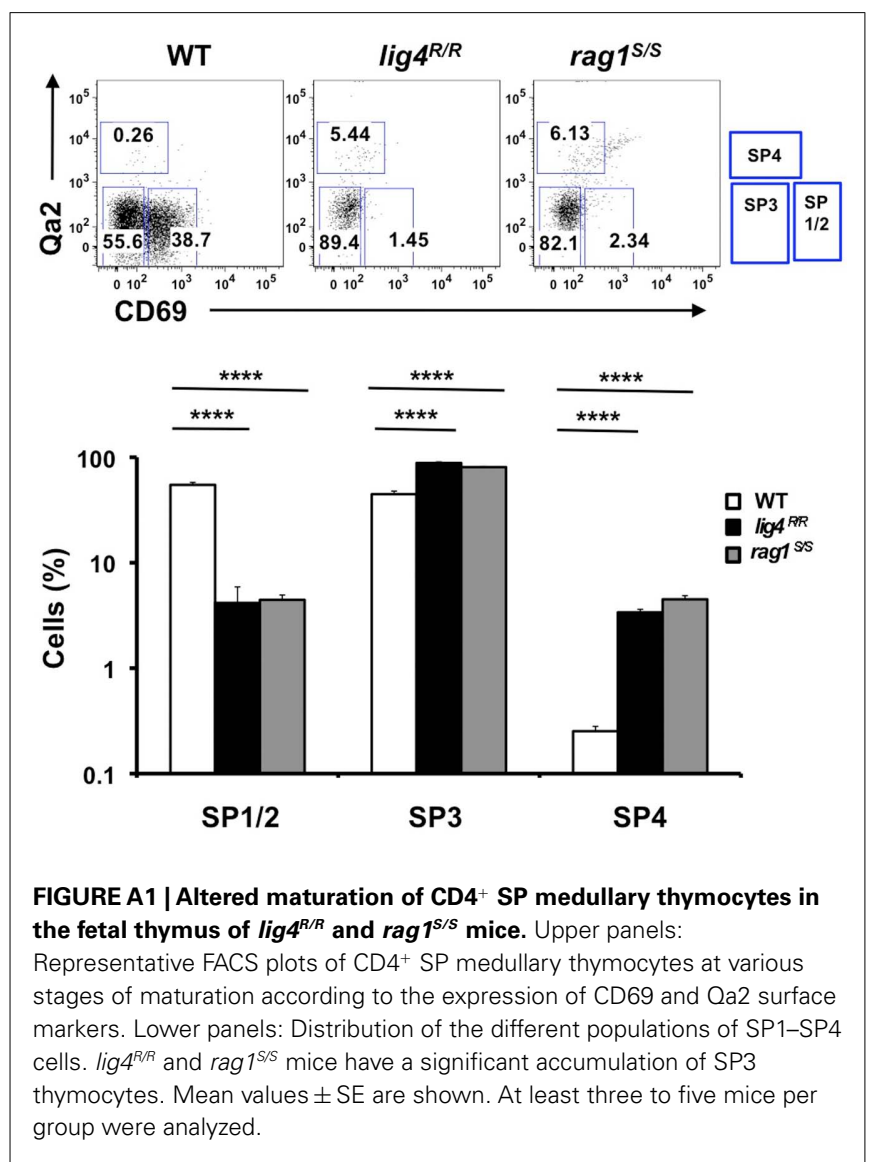

